NBER WORKING PAPER SERIES

\title{
TEACHER QUALITY AND THE FUTURE OF AMERICA
}

\author{
Peter Temin \\ Working Paper 8898 \\ http://www.nber.org/papers/w8898 \\ NATIONAL BUREAU OF ECONOMIC RESEARCH \\ 1050 Massachusetts Avenue \\ Cambridge, MA 02138 \\ April 2002
}

Presidential address to the Eastern Economic Association, March 16, 2002, Boston, MA. I thank Rob Finn and Mike Anderson for research assistance and Peter Diamond, Claudia Goldin, Eric Hanushek, Meira Levinson, Richard Murnane, and Anita Summers for advice and comments. All opinions and errors are mine alone. The views expressed herein are those of the author and not necessarily those of the National Bureau of Economic Research.

(C) 2002 by Peter Temin. All rights reserved. Short sections of text, not to exceed two paragraphs, may be quoted without explicit permission provided that full credit, including $\mathbb{C}$ notice, is given to the source. 
Teacher Quality and the Future of America

Peter Temin

NBER Working Paper No. 8898

April 2002

JEL No. I21, J45, N32

\begin{abstract}
I argue in this paper that we do not pay teachers enough to get high-quality applicants. The reasons we find ourselves in this inferior equilibrium are rooted in our history. Most American teachers are and have been women; we have not accommodated to the increasing opportunities for women in the economy today. Schools are locally funded, and we also have not accommodated to the declining effectiveness of the property tax. The result of having low-quality teachers is that current reforms sub-optimize with the current stock of teachers and therefore result at best in only small gains in educational quality. We are in danger of losing the educational advantage that the United States enjoyed in the 20th century.
\end{abstract}

Peter Temin

MIT

Department of Economics

50 Memorial Drive, Room E52-280A

Cambridge, MA 02142-1347

and NBER

ptemin@mit.edu 
Teacher Quality and the Future of America

Educational reform is on everyone's mind. President Bush announced in his campaign that education was one of his top priorities, and Congress passed a major education reform bill even in the aftermath of September 11. This reform of course is only the latest in a string of state and federal efforts that have failed to make a noticeable difference in American education. Will it be any different?

I propose to answer this question by examining the theory and history of teacher selection. I will argue that we are underpaying teachers, that is, that we are not paying teachers enough to get high-quality applicants. The result is that reforms have little effect because teachers are limited in their effectiveness. We are sub-optimizing with the current stock of teachers, rather like the short-run adjustment of a firm with a fixed capital stock. Current reforms of school administration and evaluation take the quality of teachers as given; they simply rearrange the existing educational assets and have little or no effects. Only when we break out of the current equilibrium of pay and quality will education in the United States show a marked improvement.

Others have made the point that low pay yields low quality, for example; some of them have made the point is that teachers are still predominantly women, and the job market for women has changed dramatically in the last generation. We traditionally ran our schools using a trapped labor force, but we have liberated women in the past generation. At this moment, we have not been willing to pay enough to attract highquality teachers in an open market (Murnane, 1991; Flyer and Rosen, 1997; Lakdawalla, 2001). 
Flyer and Rosen (1997) and Lakdawalla (2001) have argued that we have substituted quantity for quality as the supply price of high-quality female teachers rose. These interpretations are supported by models with unique equilibria. They tend therefore to rationalize the status quo, showing it as the solution to an optimization process. I want to argue that we are at a local optimum, but far from the global optimum. I assert that the low quality of current teachers has locked us into an equilibrium that is inferior to one we might have reached with a different history. In other words, we have not accommodated to the changing labor force participation of women in the best way for education.

This failure to compensate for the changes in our labor force has important implications for the future of the American economy. The American economy was so successful in the past century that people have begun to call it the American century. This success was due to many factors, of which avoiding a ground war on American soil surely was one. Another important factor was the broad sweep of American education. Growth theorists have noted the importance of education for economic growth, and the United States was the world leader in mass education. The American economy grew consistently during the $20^{\text {th }}$ century because we constantly upgraded the quantity and quality of our human capital (Goldin, 2001).

This achievement is now at risk. There is wide-spread dissatisfaction with the quality of education in the United States, particularly in large cities. Mass immigration to the U. S. has brought new challenges to our schools. International tests have shown that educational achievement in the United States is lagging behind that in other countries. We are in danger of losing one of the great advantages we possessed in the $20^{\text {th }}$ century. 
Unless we raise the quality of teachers, we will experience an endless sequence of failed educational reforms. If the future of America is to be as bright as the past, we need to break out of our current equilibrium.

I will make this argument in four steps. The first step is to present a simple model of teacher quality in order to frame the question. The second and third steps are to review the role of women in education and then the history of educational funding to explain the origins of today's teacher pay scales. The final step is to review some recent educational reforms, evaluate their results in light of the preceding analysis, and extrapolate these findings to the current wave of reform.

I use the Akerlof "lemon" model to understand the market for teachers. The critical assumption of this model is that the demand for teachers is a function both of price and quality. We clearly consider the quality of teachers when we hire them, imposing educational qualifications and certification; it makes sense to consider a broader index of quality as well. In particular, a high quality teacher is one who can energize and motivate students in addition to imparting information. There are no good markers for charisma and leadership, even though it can be recognized easily on an individual level. I therefore use educational success by teachers as a proxy for teacher quality. While this introduces an element of randomness, it also reinforces the connection between teachers' knowledge and their effectiveness; teachers cannot teach effectively if they do not understand the material they are teaching. (The failure of the "new math" may have resulted from the inability of most math teachers to understand it.) 
A recent paper has shown a link between teacher wages and an educational outcome, which is consistent with the view taken here (Loeb and Page, 1999).

The demand for teachers is declining in price, as for almost any other good or service, but it is increasing in quality. As Akerlof (1970) noted, if the quality is dependent on the price as well, the market may not function well. In his model, the market may not exist at all in certain price ranges. In my adaptation, there may be multiple equilibria.

Let teacher quality be indexed by $z$. On the reasonable assumption that higher wages attract higher quality teachers, $z$ will be a function of teacher wages, $w$. This function can be written as $q(w)$, the average quality of teachers when the wage is $w$. $D(w, q)$ is the demand for teachers, assuming that each hire is a random draw from the quality of teachers outstanding - decreasing in $w$ and increasing in $q . S(w ; z)$ is the supply of teachers of quality $z$ when the wage is $w$. I assume for simplicity that teachers come in only two qualities, high and low $(h, l)$. There is no problem in generalizing this model to a continuum of qualities.

The average quality of teachers, $q(w)$, can be expressed in terms of the supply of teachers:

$$
q(w)=\frac{\sum z S(w ; z)}{\sum S(w ; z)}
$$

The market clears when supply equals demand:

$$
D(w, q(w))=\sum S(w, z)
$$

The right-hand side of equation (1.2) is increasing in $w$. The left-hand side, however, may be also. Differentiating the left-hand side with respect to $w$ shows the problem. 


$$
\frac{d D(w, q(w))}{d w}=\frac{\partial D}{\partial w}+\frac{\partial D}{\partial q} q^{\prime}(w)
$$

The wage has two effects on demand. Demand is decreasing in the direct effect of $w$ but increasing in the indirect effect. If the indirect effect is larger than the direct effect over a range, then demand is upward sloping, and there can be multiple equilibria.

Using equation (1), we can evaluate $q^{\prime}(w)$ to see under what conditions the indirect effect will be positive and large:

$$
\begin{aligned}
& q^{\prime}(w)=\frac{\left(\sum S(w ; z)\right)\left(\sum z S_{w}(w ; z)\right)-\left(\sum z S(w ; z)\right)\left(\sum S_{w}(w ; z)\right)}{\left(\sum S(w ; z)\right)^{2}} \\
& =\frac{(S(w ; h)+S(w ; l))\left(h S_{w}(w ; h)+l S_{w}(w ; l)\right)-(h S(w ; h)+l S(w ; l))\left(S_{w}(w ; h)+S_{w}(w ; l)\right)}{\left(\sum S(w ; z)\right)^{2}} \\
& =\frac{S(w ; h) l S_{w}(w ; l)+S(w ; l) h S_{w}(w ; h)-\left(h S(w ; h) S_{w}(w ; l)+l S(w ; l) S_{w}(w ; h)\right)}{\left(\sum S(w ; z)\right)^{2}} \\
& =\frac{(l-h) S(w ; h) S_{w}(w ; l)+(h-l) S(w ; l) S_{w}(w ; h)}{\left(\sum S(w ; z)\right)^{2}} \\
& =(h-l) \frac{S(w ; l) S_{w}(w ; h)-S(w ; h) S_{w}(w ; l)}{\left(\sum S(w ; z)\right)^{2}}
\end{aligned}
$$

This expression is positive if the response of supply to the wage is more positively correlated with quality than is the level of supply. Let the initial fraction of high-skill teachers be $a$; the fraction of low-skill teachers then is $(1-a)$. After the wage has risen, the fractions are $a^{\prime}$ and $\left(1-a^{\prime}\right)$. If $a^{\prime}$ is greater than $a$, then the quality of teachers is more responsive to the wage than the quantity of teachers. The second term in equation (3) will be positive, and the demand for teachers could rise with the wage.

If the demand for teachers rises with the wage, then both sides of equation (2) will be increasing in w. There may be multiple equilibria, only some of which will be stable. 
I draw the example of three equilibria in Figure 1. The middle equilibrium is unstable, while the others are stable. Accordingly, there is a stable high salary, high quality equilibrium and a stable low salary, low quality one. I will argue first that the appearance of multiple equilibria in this market is relatively recent. I then will argue that we are at the lower equilibrium in Figure 1. All educational reforms will be hampered by low teacher quality as long as the wages of teachers do not rise above the wage at the middle, unstable equilibrium.

\section{II}

The United States was a world leader in public education. But throughout the nineteenth century most teachers were women. They chose to be teachers in part because most other jobs were denied to them. In this limited labor market, it is possible that higher wages would have attracted higher quality teachers, but the effect—if present at all - would have been very small. The effect of the wage on the supply of teachers undoubtedly was stronger than its effect on teacher quality. There is no reason to think there were multiple equilibria in the market for teachers before the Great Depression.

Before industrialization, almost two centuries ago, production within agrarian households was coordinated hierarchically, and there was a division of labor along gender lines. The father was head of the household, representing the family's interests in the outside world, marketing most of its output, and purchasing supplies that it could not produce for itself. The mother functioned as the father's second in command. She was supposed to be subservient to his wishes whenever he was present, but she had to be able to substitute for him and run the family enterprise in his absence. The mother also managed her own domain, which might include home manufactures and involve both 
supervising girls in various production tasks and dealing independently with outside suppliers and purchasers. In the Ballard family of Hallowell, Maine, for example, the husband, Ephraim, took charge of farm production and other enterprises such as saw milling. The wife, Martha, was a midwife, and in addition to her extensive medical practice, directed her daughters (and the other young girls who were sent from time to time to live and work with them) in the home production of textiles and other goods (Ulrich, 1990).

The history of industrialization in the nineteenth century was one of specialization, and the gender roles of men and women became more distinct as part of this process. Early industrial activities were done in the household. Men and women interacted and substituted for one another if need be, and there was opportunity for alteration of the dominant pattern when circumstances dictated. As work moved out of households, the activities of men and women diverged. Women in the household were restricted in the scope of their activities, and they had few opportunities outside the home.

The sources of paid work for Massachusetts women in the nineteenth century are shown in Table 1. In 1837, almost two-thirds of women who earned wages were working in their own homes. This outwork was part of a system known as the putting-out system in England. Initially a merchant, or putter-outer, brought raw materials to women's houses and came again to reclaim the finished product. Later women purchased the raw material at a local store and sold the product there as well.

The products made at home in Massachusetts differed sharply from the textile products made in eighteenth-century English households. The most important products were palm-leaf hats and straw bonnets. The women wove and braided split palm leaves 
into hats. Martha Alexander, for example, braided 341 hats in the 45 months before she was married in 1834. She braided 162 hats in the next two years, maintaining her prewedding pace (Dublin, 1994, p. 68). Half of the women earning wages at the beginning of this period earned their wages by braiding hats. This work however vanished completely after the Civil War.

The other important source of outwork employed only about one-fourth of the number of women employed braiding hats. This was the boot and shoe industry, in which women bound shoes, that is, sewed the lining into them and the uppers together. This source of outwork also disappeared as industrialization advanced. The sewing machine was adapted to use with leather around mid-century, and outwork was transformed into factory labor. Women were employed in these factories, but not in the proportion that they worked in the cotton textile industry.

After domestic work, the next most important employment of Massachusetts women in the 1830 s was the cotton textile industry. Unlike braiding hats at home, work in the cotton mills was for unmarried women alone. Less than a quarter of working women worked in the cotton industry at any time, but they worked there for only a short time, and a far greater proportion of women passed through the cotton mills. The textile industry became a more important source of women's work during this period, and the composition of the female workforce changed. Women began to work in the mills for longer periods, not for only a few years. These long-term operatives were not Yankee girls accumulating their dowries; they were immigrants from Ireland and French Canada. They often were married instead of being single. The cotton mills were far less inviting places to work in the early twentieth century than in the 1830 s. 
Domestic service always offered some employment for women. In the years after the Civil War, it offered the most opportunities for women as outwork declined. Onethird of Massachusetts women, and one-half of women in the United States as a whole, who earned wages worked in domestic service in 1870. (This national proportion was cut in half by 1900.) The needle trades offered another outlet for women as outwork declined (Gamber, 1997). But like work in the cotton mills, it was not either well paid nor intellectually stimulating.

Teachers increasingly were women in the nineteenth century; the proportion of teachers in Massachusetts who were women rose from half to over 85 percent (Kaestle and Vinovskis, 1980, p. 285). By the 1920s, almost all primary teachers in the United States were women (Perlmann and Margo, 2001). They never were a large proportion of employed people in New England or even of employed women, as shown in Table 1. But teachers taught on average longer than women in other occupations, an average that was composed of two quite different groups. Those teachers who followed teaching by marriage taught on average about four years, the same length of time that women originally worked in the cotton mills. But a large proportion of teachers did not marry. Twice as many teachers remained single than the average New England woman after the Civil War (30 percent as opposed to 15). These single teachers taught on average a dozen years, bringing up the average tenure of teachers (Dublin, 1994, p. 218).

The growing gender differentiation of work was summarized as follows in a history of women's work:

Among upper-and middle-class European Americans, the nineteenth-century cult of domesticity developed and formalized a division of labor in which husbands were property owners and professionals while wives were homemakers and mothers. ... At the same time, some highly educated single women interpreted the 
cult of domesticity as a call to enter the women's professions of teaching, social work, and nursing. For many, these vocations were desirable precursors to fulltime homemaking, while for others, they served as lifelong alternatives to homemaking (Amott and Matthaei, 1991, p. 298).

This pattern began to erode in the early twentieth century. As store-bought goods and services increasingly replaced those made in homes, women's unpaid work shifted from producing at home to shopping in markets. As the same time that demand for women's services declined at home, demand for them increased outside the house. Firms hired women to perform the market equivalent of homemaking, cleaning, cooking and caring for the sick. The increasing need for clerical workers and the invention of the typewriter offered better jobs to women. But the opportunities for women were still limited, although becoming more attractive (Amott and Matthaei, 1991, p. 304).

The participation of women in the labor force grew rapidly in the twentieth century, from less than 20 percent in 1890 to well over 50 percent today. The big change was for married women, whose participation rate rose from under five percent for whites and 25 percent for nonwhites to approach the participation rates of single women. As Goldin summarizes this change, "The period to about 1920 can be viewed as the era of single women's work, while that from 1920 can be depicted as the era of married women's work (Goldin, 1990, p. 57)."

Although women increased their labor force participation, they did not move immediately into a gender-blind labor force. Occupational segregation, measured by the percent of women who would have had to change occupations in order to achieve the same distribution as men, stayed roughly constant at two-thirds until 1960. This means that women in the labor force continued to have restricted job choices for two-thirds of 
the twentieth century. While the choices were not as restricted as those in Table 1, it should not be surprising that many jobs held by women were still in cotton goods, clothing, and boots and shoes (Goldin, 1990, pp. 75-79).

Only in the current generation, after about 1960, did opportunities for women open up. Before then, school boards hired women teachers in a context of little competition. Even after married women began to join the labor force in the middle years of the twentieth century, their opportunities were quite limited. Teaching remained a good job, one that was considerable more interesting and probably more attractive than the alternatives. In this context, changing teachers' wages would affect the quantity of teachers hired more than their quality. There was a unique equilibrium where the market cleared.

This has begun to change in the last few decades. The opportunities for women have become much wider, and their ability to get professional education has increased. In this new world, the brightest women will go toward the best jobs. These jobs increasingly are not teaching. Professional and technical careers now are open to women, and the brightest women quite possibly are attracted to them. In this kind of market, a higher salary for teachers will attract higher quality candidates, for they will be attracted from other interesting careers. The conditions for multiple equilibria in the model of the teacher market are now fulfilled, and conditions resemble those shown in Figure 1.

III

It is reasonable to suppose that this market is in equilibrium at one of the stable equilibria in Figure 1. How do we know it is at the lower stable equilibrium? The best 
way to tell is by comparing teacher salaries with those of comparable people in other occupations.

Murnane argued that there were many reasons why good candidates did not go into teaching, and salary was high on the list. As he noted, "In 1988, when the average starting salary for teachers was $\$ 19,600$, business and industry offered average starting salaries of $\$ 28,900$ for physics majors, $\$ 25,900$ for chemistry majors, and $\$ 21,000$ for humanities majors (Murnane, 1991, pp. 8-9)." The large salary gap for science majors surely discouraged them from entering teaching. Poor students who did not anticipate doing well in business and dedicated teachers would still go into teaching, but low salaries discouraged many bright and vigorous students. In particular, Murnane noted that low salaries discouraged women and minority group members from becoming teachers.

Looking at North Carolina where there were data on test scores by teachers, Murnane found that teachers with high test scores left teaching sooner than those who did less well. This is not surprising; we may presume that high-scoring teachers had access to better jobs than low scorers. He also found that teachers who were paid more stayed in teaching longer (Murnane, 1991, pp. 69-75). Taken together, these results showed that low salaries not only discourage good students from becoming teachers, but they also discouraged good students from remaining teachers. The results of recruitment and retention are consistent; low salaries were associated with low-quality teachers.

Flyer and Rosen standardized teacher salaries for the demographic composition of teachers. They found that, "The 'true' real wage of teachers has declined relative to wages for other college graduates, especially in elementary schools (Flyer and Rosen, 
1997, p. S119)." They noted that the real wage of teachers declined even more relative to female college graduates. Most of this decline took place in the 1970s when school enrollments fell, but relative wages have not recovered as enrollments have risen more recently.

To see what has happened in the 1990s, I examined the relationship between average teacher salaries and women aged 35-44 with five years of college. I focus on women as potential teachers. As noted above, women have seen their opportunities expand greatly in the past generation; they no longer go automatically into teaching. The wages of women have gone up as they have entered more fields, and the careers that compete with teaching have become more attractive. This comparison may be approached by examining the wages of women with more than a college education.

A clear picture emerges from the Current Population Survey (CPS). I compare teachers to females with some graduate education in Figure 2 to capture the comparison between teachers and women who have goen on to get degrees in subjects other than education. Highly educated women who were not teachers earned more than teachers throughout the past twenty years. The wage premium stayed under 20 percent until around 1987, and it has risen steadily and strongly since then. The wage premium for women who have some graduate education and are not teachers is now 40 percent. This trend shows that teacher salaries are falling behind those of high-quality education women at a rather rapid rate.

The data shown in Figure 3 extend this story. Many high-school teachers have masters degrees, but most elementary teachers do not. The comparison shown in Fgiure 2 therefore may not be accurate for teachers of lower grades; I have compared them with 
women who have more education than they do. I cannot distinguish teachers by grade in the CPS, but I can compare teacher salaries with women who have only college degrees. This comparison is shown in Figure 3. The two graphs look very similar. The trends are very much the same, although they divergence of wages is less strong in Figure 3 than in Figure 2. Women with some graduate education now earn on average 40 percent more than teachers; women with just college education earn on average about ten percent more than teachers. Flyer and Rosen (1997) argued that relative wages for elementary teachers fell in the 1970s; they have declined again in the 1990s.

These comparisons of earnings tell only part of the story. The career choices open to women have expanded greatly in the past generation, as narrated briefly in the previous section. This, coupled with the growth of women with extensive labor-force experience, has resulted in rising earnings for professional women. In addition, it has opened up jobs that are more interesting and challenging, careers that are more fulfilling. If there were a way to adjust for the expanding choices of educated women, the gap between teacher earnings and alternative "earnings" would be larger than those shown here.

It perhaps is not strange that those who set teacher salaries have been slow to appreciate changes in the overall labor force. We may be observing only a delay in the adjustment of teacher salaries to their new context. There are however reasons to suspect this story of a long transition. The sources of funds for schools are limited, even despite the sense of a national emergency in education. The theoretical model I have presented here also suggests that we are in a low-wage equilibrium, and it will be hard to get out of it. I describe these two problems in turn. 
American schools are funded locally, as they have been since time immemorial. This was a strength of the educational system in its great expansion early in the twentieth century. States and localities that desired to expand education, particularly high schools, could raise money and implement their plans more or less on their own. This local control of the education and its funding was an important factor contributing to the educational lead of the United States over Europe for much of the century (Goldin, 2001).

The dominant source of funding for schools was the property tax. This was an ideal local tax since land cannot move to escape the reach of the taxes. Of course, people can move, selling land and driving down its price. The property tax therefore had to be used for public improvements that would retain population, a good incentive for local taxes and expenditures. The property tax also was a traditional American tax that had served its collectors well. Before the Great Depression, about 40 percent of all government revenues came from this tax (Wallis, 2000, p. 71).

Then something happened. The share of government revenues raised from property and income taxes is shown in Figure 4. During the Great Depression and the Second World War, the share of taxes collected by property taxes plunged from 40 percent to around five percent. The share of income taxes skyrocketed in an almost mirror image. This dramatic change of course is a reflection of the equally dramatic expansion of the federal government. The revenue needs of Social Security and of the Cold-War military were provided through payroll and income taxes, dwarfing the revenues of the property tax. The transformation of the economy away from land-based activities like agriculture and manufacturing also has made income taxes more efficient sources of revenue than property taxes. 
In addition, court decisions trying to equalize school expenditures across local jurisdictions have accentuated the problem of school funding. The requirements that spending be equalized can be thought of as a tax on educational spending that hits those who spend the most. They penalize those people with a high demand for education relative to other people with the same income. The result is that the way in which the legitimate desire for equal spending has been implemented has led to lower overall spending. Strong equalization schemes, mostly notably in California, have had the most dramatic negative results (Hoxby, 2001).

The result of all this pressure on school funding has been to push us onto the lower stable equilibrium in Figure 1 when the changing nature of the female labor market gave rise to multiple equilibria. Finding themselves with lower quality teachers, school districts imposed work standards on teachers to make sure they were doing their jobs. These restrictions on teacher creativity made teaching an even less desirable job than indicated by the salary. The interaction of quality and work rules set up a dynamic process that decreased the former and increased the latter. This has created a stable equilibrium to which the teacher market will return after small shocks.

The stability of this equilibrium is embodied in work rules that have been imposed to support this equilibrium. If teachers are of low quality, then they need to be carefully controlled and monitored in order to make sure they are doing their jobs. This comes out most vividly in the relations between teachers and administrators. The latter feel obliged to keep tight control of the teachers, and feel free to discipline them in front of their students. This process humiliates the teachers at the same time as it undermines their authority. Teachers are publicly criticized for not keeping their lines straight, for 
not being in "homeroom circle" properly and for other minor infractions of classroom neatness. A Boston middle-school teacher told me that her principal yelled at her for forsaking her lunch duty place briefly to get food for a student whose lunch she had had to confiscate earlier. This is precisely the kind of discipline designed to discourage all but the most dedicated of creative teachers.

Standardized tests are a way of monitoring teacher performance. Continual testing has become very popular in the current discussion of education, and it is the cornerstone of the new federal education bill. It is clear in the bill that the purpose of the tests is to evaluate the schools and the teachers within it. Tests previously were to evaluate students, but far fewer tests than the annual ones proposed in current policies were sufficient for this purpose. The new policies are to keep a tight reign on teachers rather than students.

Tests, like humiliating disciplinary actions, make life miserable for teachers. They force teachers to teach to the tests, reducing scope for any creative teaching. They direct attention to skills that can be measured on annual objective tests and away from learning that is more subtle or long-term. For example, we support public schools in part to promote civic responsibility (Levinson, 1999). It is not clear how one would test this by multiple choices or if one would look for steady year-to-year increases in this set of attitudes. Less tangible and more creative parts of teaching therefore are discounted relative to the basic mechanics of teaching. If low salaries do not drive creative teachers away, excessive discipline and annual tests should do so. In a cruel but not unexpected irony, the lowest quality teachers are in urban schools (Lankford, Loeb and Wyckoff, 2001). 
I do not mean to throw the baby out with the bath-water. As noted above, we evaluate teachers through their success at taking tests during their education. And any dramatic increase in teacher salaries will have to be accompanied with an increase in teacher accountability, which inevitably will have to be measured by some sort of tests. Current tests appear only to be aimed at evaluating minimum competence. They tend to stultify the most creative teachers even as they, at least in theory, help the worst students.

Principals also may be part of the problem rather than part of the solution. They are recruited from teachers, and their quality has moved with that of the pool from which they come. The demands on principals in the low equilibrium—-to preserve order and maintain the school building-were consistent with their abilities. If we seek to move to a different equilibrium, where good teachers will be rewarded for excellence and all teachers will be held accountable for their performance, it is far from clear that the current stock of principals will be able to administer such a system. To make tests an effective device for monitoring and rewarding quality, school administration as well as the tests themselves will have to be improved almost beyond recognition.

Teacher unions have responded to all of these attempts to control and monitor their members. They fight these attempts to micro-manage teachers on two grounds. They are demeaning to teachers, and they are administered by people who themselves are not trustworthy. The "management" opposing teachers consists both of principals, as just discussed, and departments of education. The unions of course have only limited tools available to them, and they have chosen to restrict the activities of administrators in their defense. They have done so by making it hard to fire teachers and hard to deviate from a 
simple job description. These union rules add to the administrative rules to keep the teacher market at the low-quality equilibrium.

One implication of being at a stable equilibrium is that small efforts to move the market will have limited and temporary effects. The market will return to its equilibrium after small shocks. This is why current educational reforms universally have failed. They may or may not have an impact effect, but the crisis in education is ongoing, despite the plethora of curative policies that have been implemented in the past decade or so.

Consider, for example, the movements for educational vouchers and charter schools. These campaigns share their attempt to solve the problems with American education by a change in its administration — and not by spending more to get better teachers. Even if we grant that current educational administration is poor, in part for the reasons cited earlier, the most these reforms can do is sub-optimize with the current quality of teachers. But they do not seem to have done even that. A recent survey of all the empirical results of these policies turned up almost no effects at all on students. This RAND study evaluated vouchers and charter schools on several dimensions, ranging from academic achievement to civic socialization. The authors noted that the evidence was quite sketchy for many dimensions and for short duration on most of them. They concluded that there was almost no evidence of gain from these administrative changes. A "modest achievement benefit for African-American students after one or two years in voucher schools" was the most they could tease out of the available evidence (Gill, et al., 2001, p. 203).

The evidence for testing is similar. As noted above, testing has been transformed recently into a means of monitoring teacher and school performance. There does not 
seem to be any evidence to date that it succeeds in this aim. In fact, the evidence appears to be that testing is a very noisy signal of school quality. Testing results exhibit randomness and regression toward the mean that suggests that the results are mostly noise. A school that does spectacularly well (badly) in one year is very likely to go badly (very well) in the next. This is exactly the kind of behavior we expect from a signal observed with large uncorrelated errors. In the words of one author, the rankings are effectively random (Figlio, 2001; Kane and Staiger, 2001; Figlio and Page, forthcoming).

Is the past a good guide for the future? I think it is in this case. I have argued that we are in a stable equilibrium of low-quality teachers. Small shocks, which is what these reforms are, will not disturb the equilibrium. In fact, the model predicts that any reform that is described as not needing a large infusion of cash into American education will be doomed to failure. There is no substitute for breaking out of the lower equilibrium far enough to approach the higher one.

I hope that the people of the United States will make this effort soon, but there is little chance that we will try to make this jump any time soon. Two reasons militate against it. First, the recession has deprived US governments of revenue to spend on education. The federal government has gone from surplus to deficit in short order, and the Bush tax cut ensures that it will not emerge from red ink any time soon. State governments cannot run deficits as the federal government can, and they are facing difficult choices funding existing programs. Medicaid is likely to suffer, and educational reform costing more money is not even on the table (Pear and Toner, 2002). As state support for localities diminishes, even local spending will be adversely affected. Teachers are liable to be paid less, rather than more, and even lose jobs. 
Second, the rules enforced by unions defending their current positions make it hard to move from one stable equilibrium to the other. For example, teacher unions generally insist on uniform pay scales for all teachers. Science teachers are in most short supply because the wages that scientifically-inclined young women can earn outside teaching are the highest. But union rules typically do not allow school districts to pay differential salaries according to the subject taught. A rule mandating equal pay means that salaries cannot be raised selectively, and this implies that any attempt to move to a higher equilibrium will be costly indeed.

In addition, the work rules unions have supported to protect teachers in the current equilibrium make teaching unattractive for creative and skilled people. They would have to be relaxed and even eliminated in order to reinforce a new equilibrium. With higher pay should come more job autonomy. With autonomy comes individual responsibility, and with that comes a decline in teacher solidarity. Such a reform might be good for most current teachers and good for students, but it may be hard for unions to move toward it. They are responsive to members who have come into the profession in the old equilibrium and do not want to change, and their very existence could be threatened by the growth of individual teacher responsibility. The randomness of existing tests reinforces this resistance, and tests will have to be improved markedly to make them appear attractive to some teachers.

Teacher unions rose to prominence in the 1960s attempting to move the teacher market from the lower to the upper equilibrium in Figure 1. Actually, since the market was changing at that same time, the early teacher unions may have been trying to raise wages in a unique equilibrium, which in time would have turned into the upper 
equilibrium in Figure 1. The trend toward smaller classes of recent decades also was supported by the unions as a way of increasing the demand for teachers, with the concurrence of academics and policy makers who agreed that smaller classes enhanced education. Teacher unions, in other words, were a progressive force in education a generation ago, and they have only become a brake on progress recently. They perhaps should be included in the list of American educational institutions that were advantages earlier and have become hindrances today (Goldin, 2001).

This argument can be summarized as follows. Effective school reform in the United States faces great hurdles. There are no forces moving the demand for teachers upward; if anything, we are facing a sustained decline in the effective demand for teachers. There also are no forces moving the supply of teachers upward in the short run. Teacher unions will oppose strongly any changes that threaten them; they will not allow individual choices to move toward a new equilibrium. Of course, since the demand curve is not shifting upwards, there is no expectation that we are to jump to the higher stable equilibrium, and the union response is rational.

IV

I have argued in this paper that the market for teachers today is characterized by multiple equilibria. This phenomenon appears because the demand for teachers depends on their quality as well as their wage. This did not cause any problems, that is, multiple equilibria, in the past because there was a limited market for the services of women. Women went into teaching as much for the challenge it posed as for the wage, and quality was not highly dependent on the wage offered. Women's liberation has allowed 
women to choose jobs, and they have moved into a variety of interesting positions in the last generation. The quality of teachers became responsive to the salary offered as a result, and multiple equilibria appeared.

We have found ourselves at a lower equilibrium as a result of inadequate school funding. That inadequacy was traced here to the reliance on the property tax, but it may be more general. The market of nurses seems to fit this same story, at least to a first approximation. And teachers in many other industrial countries also are badly paid relative to the salaries of professional women (Lakdawalla, 2001). These casual observations suggest that there may be forces additional to our reliance on the property tax that have propelled us to the lower equilibrium.

The implication of this analysis is that it will be very hard to improve the quality of American schools. We will need a concerted effort to break out of this stable equilibrium, attract a new breed of teachers, and settle into a new higher paying equilibrium. None of the current reforms even comes close to making that attempt. They are doomed to failure as a result, and the available empirical evidence suggests that they are in fact failing. We all hope for progress, in the long run, if not immediately.

If the quality of American schools does not improve, however, the American century may the description of a limited period of time. It will describe the $20^{\text {th }}$ century, but not the $21^{\text {st }}$. Social Security will be in trouble in future years both because of retiring baby boomers and because of low wages for poorly educated workers. It is not a cheerful prospect. 
Table 1

Occupational Distribution of Wage-Earning Women in Massachusetts (percent)

\begin{tabular}{|l|c|c|}
\hline Industry & 1837 & 1870 \\
\hline Palm-leaf hats (outwork) & 49 & -- \\
\hline Textiles & 17 & 26 \\
\hline Boots and shoes (outwork) & 14 & 5 \\
\hline Domestic service & 12 & 34 \\
\hline Teaching & 4 & 5 \\
\hline Men's and women's clothing & 3 & 18 \\
\hline Other & 1 & 12 \\
\hline
\end{tabular}

Source: Temin, 2000, p. 136. 
Figure 1

Supply and Demand for Teachers with Multiple Equilibria

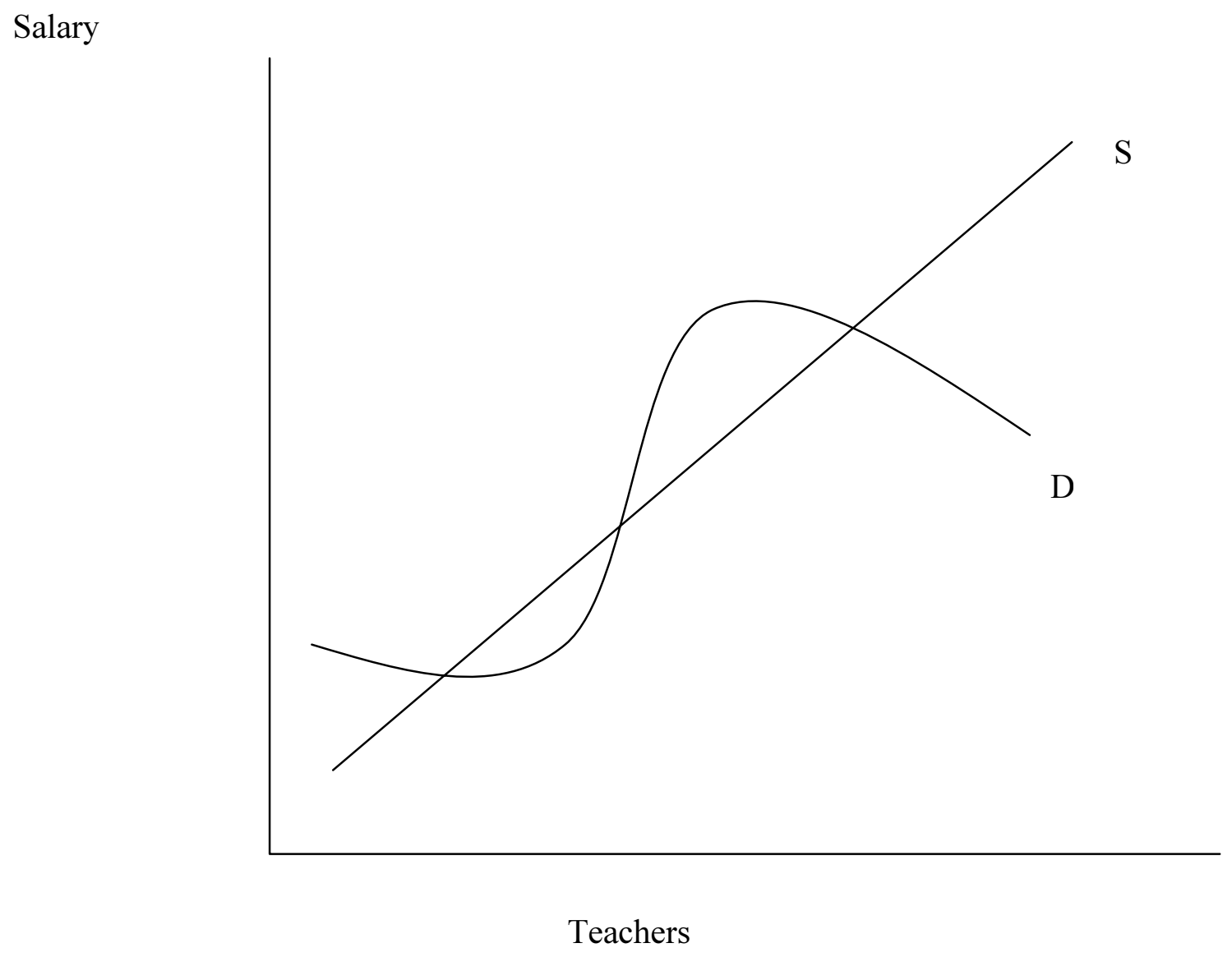




\section{Figure 2}

Ratio of Wages for Females with Graduate Education to Female Teachers, 35-44, 1979-99

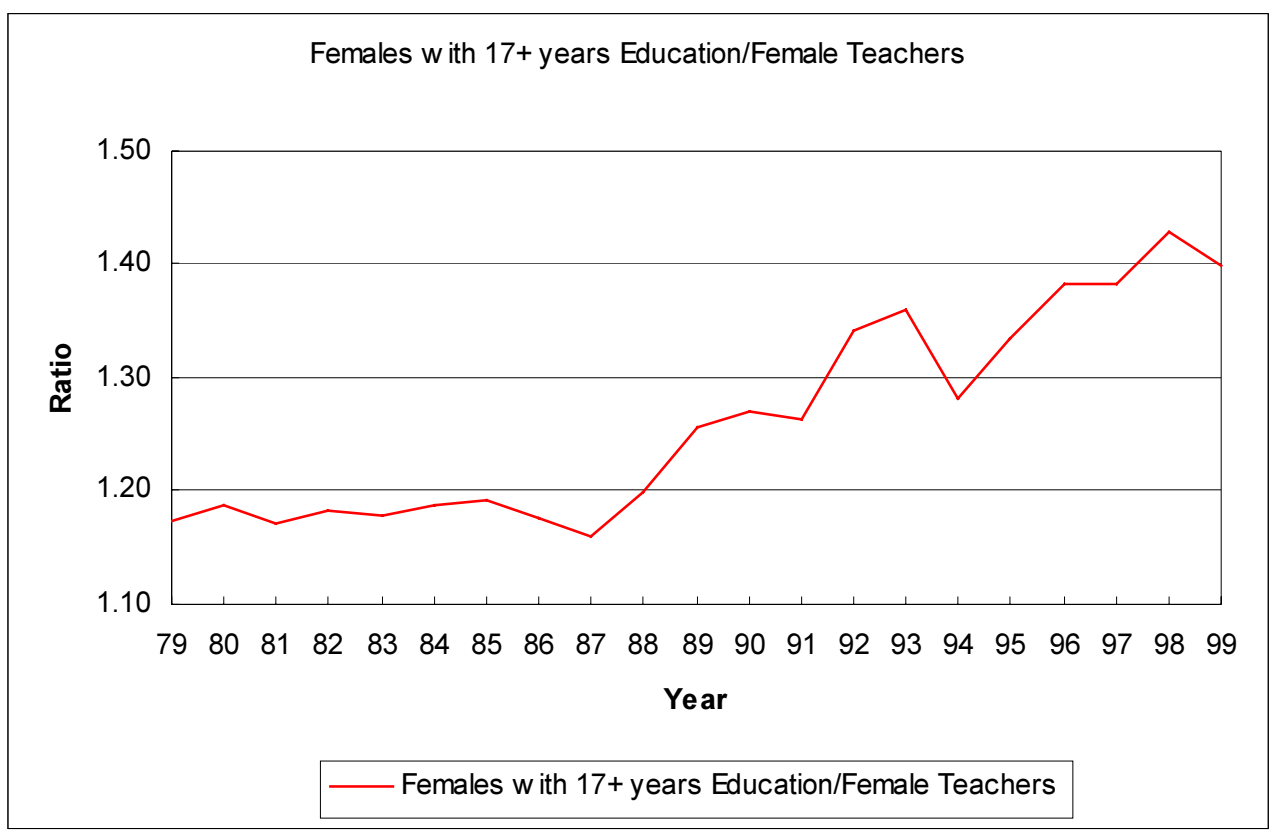

Source: Current Population Survey, Merged Outgoing Rotation Groups, 1979-99. 
Figure 3

Ratio of Wages for Females with College Education to Female Teachers, 35-44, 1979-99

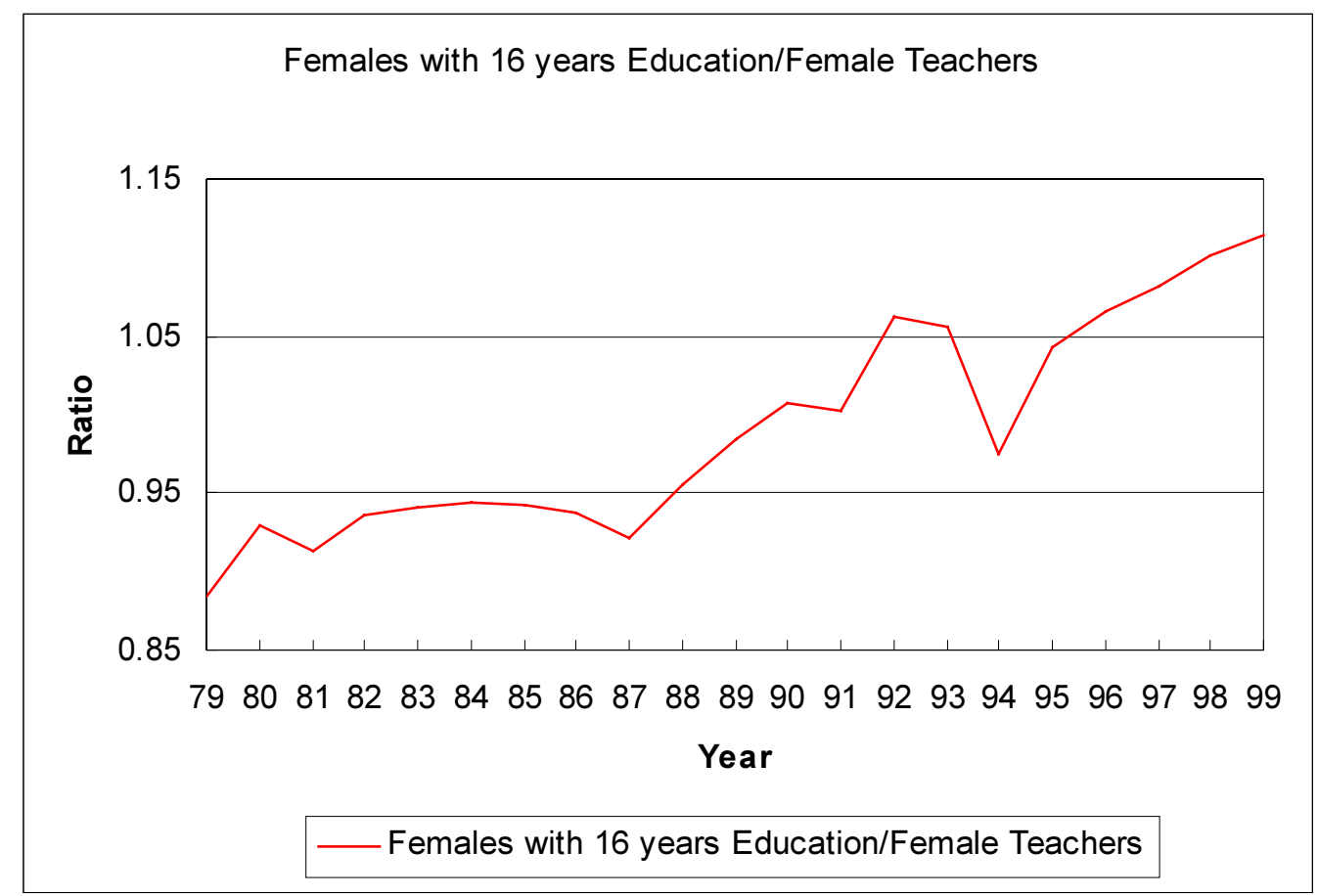

Source: Current Population Survey, Merged Outgoing Rotation Groups, 1979-99. 


\section{Figure 4}

Share of Total Government Revenue from Property and Income Taxes

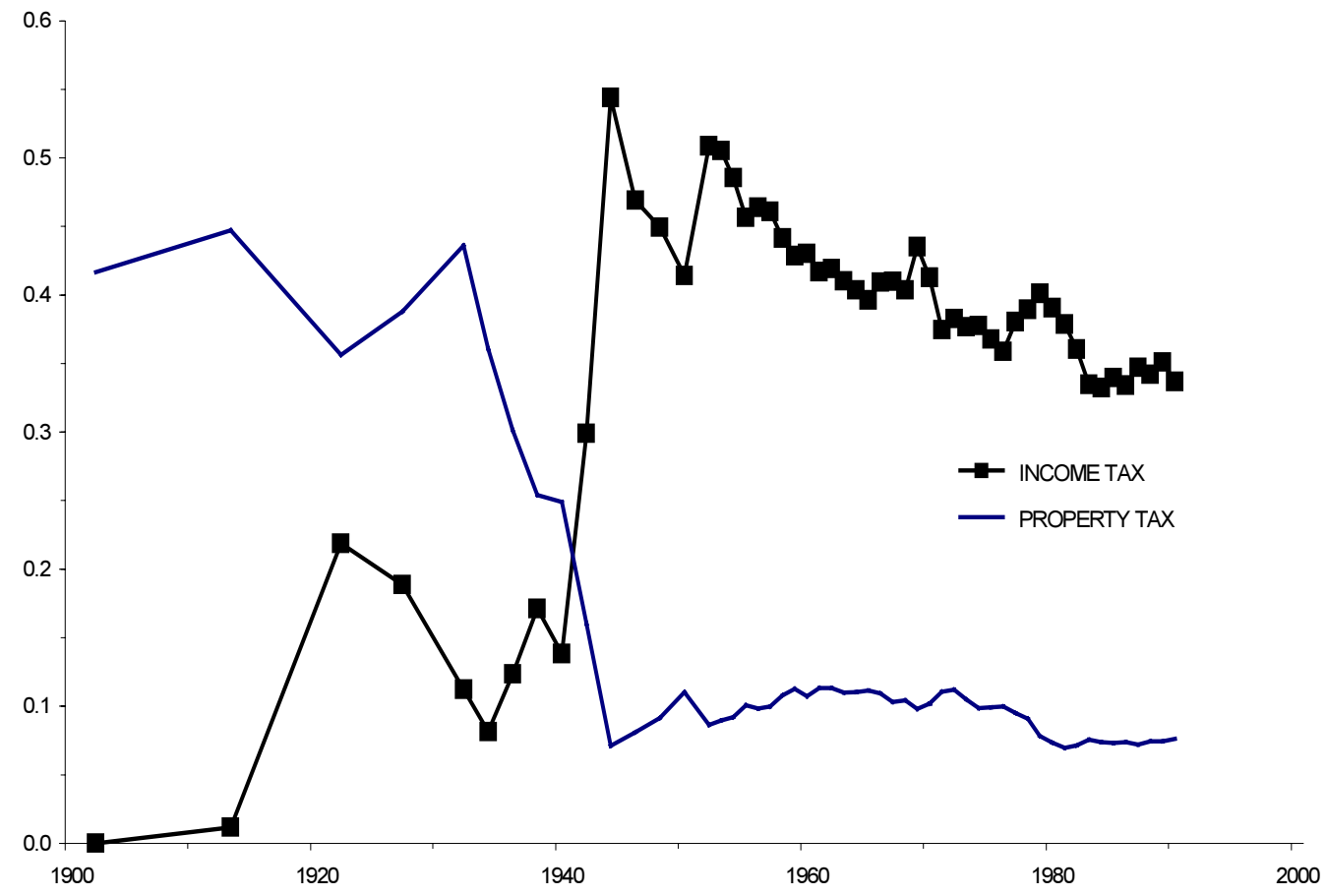

Source: Wallis, 2000, p. 71. 


\section{References}

Akerlof, George A., “The Market for 'Lemons': Quality Uncertainty and the Market Mechanism," Quarterly Journal of Economics, 84 (August 1970), 484-500.

Amott, Teresa L., and Julie A. Matthaei, Race, Gender, and Work: A Multicultural Economic History of Women in the United States (Boston, MA: South End Press, 1991).

Dublin, Thomas, Transforming Women's Work: New England Lives in the Industrial Revolution (Ithaca, NY: Cornell University Press, 1994).

Figlio, David N., "What Might School Accountability Do? NBER Reporter, Fall 2001, pp. 7-10.

Figlio, David N., and Marianne E. Page, "Can School Choice and School Accountability Successfully Coexist?” in Caroline M. Hoxby (ed.), The Economics of School Choice (Chicago: University of Chicago Press, forthcoming).

Flyer, Fredrick, and Sherwin Rosen, "The New Economics of Teachers and Education," Journal of Labor Economics, 15, supplement (January 1997), S104-S139.

Gamber, Wendy, The Female Economy: Millinery and Dressmaking Trades, 1860-1930 (Urbana, IL: University of Illinois Press, 1997).

Gill, Brian P. et al., Rhetoric versus Reality: What We Know and What We Need to Know About Vouchers and Charter Schools (Santa Monica, CA: RAND, 2001).

Goldin, Claudia, Understanding the Gender Gap: An Economic History of American Women (New York: Oxford University Press, 1990).

Goldin, Claudia, "The Human Capital Century and American Leadership: Virtues of the Past," Journal of Economic History, 61 (June 2001), 263-92. 
Hoxby, Caroline M., "All School Finance Equalizations Are Not Created Equal,” Quarterly Journal of Economics, 116 (November 2001), 1189-1231.

Kaestle, Carl F., and Maris A. Vinovskis, Education and Social Change in the Nineteenth-Century Massachusetts (Cambridge, England: Cambridge University Press, 1980).

Kane, Thomas J., and Douglas O. Staiger, "Improving School Accountability Measures," NBER Working Paper No. 8156 (2001).

Lakdawalla, Darius, “The Declining Quality of Teachers,” NBER Working Paper 8263 (April 2001).

Lankford, Hamilton, Susanna Loeb, and James Wyckoff, "Teacher Sorting and the Plight of Urban Schools: A Descriptive Analysis," MS, 2001.

Levinson, Meira, The Demands of Liberal Education (New York: Oxford University Press, 1999).

Loeb, Susanna, and Marianne E. Page, "Examining the Link Between Teacher Wages and Student Outcomes: The Importance of Alternative Labor Market Opportunities and Non-Pecuniary Variation," Stanford University, manuscript, June 1999.

Murnane, Richard J., et al., Who Will Teach? Policies That Matter (Cambridge, MA: Harvard University Press, 1991).

Pear, Robert, and Robin Toner, "Amid Fiscal Crisis, Medicaid is Facing Cuts from States, The New York Times, January 14, 2001, p. 1.

Perlmann, Joel, and Robert A. Margo, Women's Work? American Schoolteachers, 16501920 (Chicago: University of Chicago Press, 2001). 
Temin, Peter, "The Industrialization of New England, 1830-1880," in Peter Temin (ed.), Engines of Enterprise: An Economic History of New England (Cambridge, MA: Harvard University Press, 2000), pp. 109-52.

Ulrich, Laurel Thatcher, A Midwife's Tale: The Life of Martha Ballard, Based on her Diary, 1785-1812 (New York: Alfred A. Knopf, 1990).

Wallis, John Joseph, "American Government Finance in the Long Run: 1790-1990," Journal of Economic Perspectives, 14: 61-82 (Winter 2000). 